Jurnal

Belo
Volume 6 Nomor 1 Agustus 2020 - Januari 2021 DOI: https://doi.org/10.30598/belovol6issuelpage32-47 p-ISSN : 2460-6820 | e-ISSN : 2686-5920

Penerbit : Fakultas Hukum Universitas Pattimura

\title{
Strategi Pengawasan Pelanggaran Pidana Pemilu Pada Daerah Kepulauan Maluku
}

\author{
Tarsisius Sarkol ${ }^{1, *}$ \\ ${ }^{1}$ Sekolah Tinggi Ilmu-Ilmu Sosial (STIS). Tual \\ sat.ameks@gmail.com ${ }^{1}$
}

* Corespondence Author

\begin{abstract}
Abstrak
Fungsi Bawaslu Provinsi, Kota Kabupaten/Kota diperluas dengan Undang-Undang tentang pemilu, Bawaslu dapat melaksanakan Mediasi, dan Proses Adjudikasi, namun dibatasi dengan waktu yang sangat singkat, sementara rentan kendali yang luas, dengan $92 \%$ wilayah laut dan $8 \%$ wilayah darat. Tujuan penulisan ini untuk mengetahui strategi pengawasan pemilu pada daerah kepulauan Maluku. Metode yang dipakai adalah yuridis normatif, dengan sumber bahan hukum primer, sekunder dan tresier. Hasil penelitian menunjukan bahwa dengan rentan waktu yang cepat namun wilayah yang luas maka di era revolusi 4.0, pengenegakan hukum dengan memakai basis teknologi informasi dan komunikasi, dengan ini maka tidak akan terkendala waktu dan rentan wilayah.
\end{abstract}

\section{Kata Kunci: Strategi, Pengawasan, Kepulauan}

Naskah dikirim: 17 Juli 2020|Direvisi : 10 Agustus 2020|Diterbitkan: 25 Agustus 2020

\begin{abstract}
The functions of the Provincial Bawaslu, City District / Cities are expanded with a law on elections, Bawaslu can carry out Mediation and Adjudication Processes, but it is limited by a very short time, while being vulnerable to extensive control, with $92 \%$ sea
\end{abstract}


area and $8 \%$ land area. The purpose of this paper is to determine the election supervision strategy in the Maluku islands. The method used is normative juridical, with primary, secondary and tresier legal materials. The results showed that with a fast time vulnerability but a large area, in the era of revolution 4.0, law enforcement using the basis of information and communication technology, with this it will not be constrained by time and vulnerable areas.

\section{Keywords : Strategy, Supervision, Archipelago.}

\section{Pendahuluan}

Peralihan kekuasaan merupakan sebuah hal yang lumrah dalam sebuah Negara, di Indonesia telah terjadi beberapa pergantian kekuasaan melalui Pemilihan Umum, sampai dengan akan diselanggarakan Pemilihan Umum Tahun 2019. ${ }^{1}$ Pergantian kekuasaan ini dilakukan dengan damai, dengan menyalurkan pilihan rakyat kepada calon tertentu yang akan mewakili suaranya, dengan jalan melakukan vote pada pilihannya melalui sistem pemilu yang demokratis. Peralihan kekuasaan ini harus dilakukan secara jujur dan adil supaya tidak muncul pemimpin yang tidak baik. ${ }^{2}$

Joseph A. Schumpeter dalam bukunya yang berjudul Capitalism, Socialism \& Democracy mendefenisikan demokrasi adalah serangkaian proses untuk membuat keputusan dan cara memperoleh kekuasaan dengan memperebutkan suara raktyat secara kompetitif. ${ }^{3}$ Demokrasi dimaknai sebagai metode politik yang berisi serangkaian prosedur kelembagaan untuk mencapai keputusan politik dengan cara memperbutkan suara rakyat, Schumpeter menegasakan bahwa kedaulatan rakyat harus dipertahankan dalam ranah proseduralis dengan memperkuat tiga elemen kunci, yaitu, parlemen yang kuat, sistem partai yang kompetitif dan pemilihan bebas, adil, dan terbuka, dalam hal

${ }^{1}$ Zuhro, R. S. (2019). DEMOKRASI DAN PEMILU PRESIDEN 2019. Jurnal Penelitian Politik Lipi, Volume 16 Nomor 1 69-81

${ }^{2}$ Patty, J. (2020). jmp Pelarangan Mantan Terpidana Korupsi Menjadi Calon Kepala Daerah Agar Menimbulkan Efek Jera. Jurnal Belo, Volume 5 Nomor 1, Hal 1-9.

3 Joseph A. Schumpeter, Capitalism, Socialism and Democracy, (2016) Publisher: Routledge. Hal 
ini, kedaulatan rakyat melalui pemilian umum dianggap sebagai alat legitimasi elite dalam membuat keputusan publik. ${ }^{4}$

Pemilihan bebas, adil, dan terbuka, inilah sering menjadi permasalahan dalam implementasinya di lapangan, bagaimana jika pemilu itu tidak dilakukan sesuai dengan asas pemilu yaitu bebas, adil dan terbuka. Maka dibutuhkan sebuah lembaga yang melakukan pengawasan agar pemilihan bisa berjalan dengan baik. Lembaga Pengawasan Pemilihan Umum di Indonesia dikenal dengan nama Badan Pengawasan Pemilihan Umum (Bawaslu), setelah dikeluarkan Undang-undang Nomor 7 Tahun 2017 tentang Pemilihan Umum (UU Pemilu), Lembaran Negara Republik Indonesia Nomor 182, UU Pemilu mengamanatkan Bawaslu mempunyai tugas dan fungsi baru dalam melakukan pengawasan. Tugas dan fungsi baru ini adalah ;

a. menerima, memeriksa dan mengkaji dugaan pelanggaran Pemilu;

b. menginvestigasi dugaan pelanggaran Pemilu;

c. menentukan dugaan pelanggaran administrasi Pemilu, dugaan pelanggaran kode etik Penyelenggara Pemilu, danTatau dugaan tindak pidana Pemilu; dan

d. memutus pelanggaran administrasi Pemilu. (vide Pasal 94 ayat (2) UU Pemilu)

Teknis pelaksanaan tugas dan fungsi ini diatur dalam peraturan Bawaslu, namun dalam melakukan penegawasan pemilu yang dilakukan sering mengalami kendala karena Wilayah Maluku yang sebagaian bersar terdiri dari laut (Luas Provinsi Maluku $712.479,55 \mathrm{Km}^{2}$ dengan luas daratan 54.185, $42 \mathrm{Km}^{2}(8 \%)$ dan luas perairan 658.294,65 Km² (92\%). Sehingga kabupaten/kota yang berbentuk daerah kepulauanpun mengalami kendala yang sama, sementara Undang-undang Pemilu dan peraturan Bawaslu belum menjawab sepenuhnya masalah tersebut hal ini yang menjadi kebaharuan dalam penulisan ini. Untuk itu diperlukan strategi pengawasan yang sesuai dengan daerah Kepulauan.

Metode Penelitian yang dipakai oleh penulis dalam penulisan ini adalah

a. Jenis Penelitian

4 Held David, 2007, Globalization/ Anti-Globalization: Beyond the Great Divide Polity, Cambridge. Hal 165

DOI: https://doi.org/10.30598/belovol6issue1page32-47 
Berdasarkan judul dan permasalahan tersebut, maka jenis penelitian yang digunakan dalam penulisan ini adalah Yuridis Empiris, Metode Pendekatan yang digunakan dalam penelitian ini adalah metode yuridis empiris. Penelitian yuridis empiris adalah penelitian hukum mengenai pemberlakuan atau implementasi ketentuan hukum normatif secara in action pada setiap peristiwa hukum tertentu yang terjadi dalam masyarakat. ${ }^{5}$

b. Tipe Penelitian

Penulisan ini bersifat deskriptif analitis, dimana dengan menggunakan pendekatan di atas dapat didiskripsikan berbagai temuan yang akan dianalisis dan dibahas dalam suatu sistem penelitian sehingga dengan hasil deskripsi tersebut dapat ditarik suatu kesimpulan dan dilengkapi dengan saran-saran. ${ }^{6}$

c. Sumber Data

Penelitian ini memakai data primer, yaitu data yang diperoleh langsung dari lapangan dengan wawancara. dan data sekuder berupa :

Bahan hukum primer, yaitu Undang-undang Nomor 7 Tahun 2017 tentang Pemilihan Umum, dan peraturan dibawahnya. Bahan hukum sekunder yaitu, Majalah, Jurnal Hukum, dan Bahan non hukum yaitu, Kamus Hukum, Ensiklopedia serta sarana ajar tentang tata cara penulisan karya ilmiah, dan dilengkapi dengan bahan hukum tersier.

4. Teknik Pengumpulan dan Analisis Data.

Setelah semua data yang dibutuhkan terkumpul, kemudian dilakukan pemeriksaan terhadap data baik melalui wawancara dan inventarisasi data tulis yang ada. Kemudian data diolah dan disusun secara sistematis. Jika sifat data yang dikumpulkan hanya sedikit, bersifat monografis atau berwujud kasus-kasus, sehingga hal 168

5 Amirudin, et.al, (2006) "Pengantar Metode Penelitian Hukum”, RajaGrafindo Prasada, Jakarta. ${ }^{6}$ Soekanto Soejono, (2016) Pengantar Penelitian Hukum, UI Press, Jakarta,hal 10 
tidak dapat disusun ke dalam suatu struktur klasisfikasi, data yang telah didapat kemudian dianalisis dengan analisis kualitatif .

Berbicara tentang pengawasan, maka harus dilihat kata dari pengawasan adalah ada orang yang melakukan fungsi mengawasi, dan proses mengawasi tersebut, "control is to determine what is accomplished, evaluate it, and apply corrective, measures, if needed to ensure result in keeping with the plan" (Pengawasan adalah menentukan apa yang telah dicapai, mengevaluasi dan menerapkan tindakan korektif, jika perlu, memastikan hasil yang sesuai dengan rencana), sebagaimana dikemukakan oleh guru besar dari Ball State University, George Roberth Tery dalam Muchsan. ${ }^{7}$

Sedangkan guru besar dari Universitas Padjadjaran Bagir Manan mengatakan control adalah sebuah fungsi sekaligus hak, sehingga lazim disebut sebagai fungsi kontrol atau pengendalian. ${ }^{8}$ Pegawas yang baik adalah pengawas yang mempunyai integritas. ${ }^{9}$ Pelaksaan pengawasan dimulai dari tahapan perencanaan, pelaksaan sampai pada evaluasi, pengawasan berhubungan dengan pembatasan, sedangkan jika dilihat tentang pengedalaian maka adakan berhubungan dengan arahan. Badan Pengawas Pemilu diberikan "hak" dan "fungsi" oleh undang-undang untuk melaksanakan pengawasan. Pembangunan sistem pengawasan kebanyakan hanya berfokus pada hak saja, sehingga tidak membangun suatu sistem yang bertanggungjawab (accountable).

Fungsi-fungsi yang diberikan oleh undang-undang harusnya dikordinasikan dengan baik, hal isi sesuai dengan tuntutan profesi yang akan berujung pada hasil dari pengawasan yang dikehendaki, mutu dari yang diharapkan tergantung dari proses dan menajemen pengawasannya.

\footnotetext{
${ }^{7}$ Muchsan, (2007) Sistem Pengawasan Terhadap Perbuatan Aparat Pemerintah Dan Peradilan Tata Usaha Negara Di Indonesia, Liberty, Yogyakarta. Hal 12

8 Bagir Manan, (2012) Teori dan politik konstitusi, Direktorat Jenderal Pendidikan Tinggi, Departemen Pendidikan Nasional, hal 1-2

${ }^{9}$ Rahmatunnisa, M. (2017). MENGAPA INTEGRITAS PEMILU PENTING?, Jurnal Bawaslu, Volume 3 Nomor 1, Hal 1-11.
} 


\section{Pembahasan.}

Dalam sambutan buku Teguh Prasetyo tentang Pemilu Bermartabat (Reorientasi Pemikiran Baru Tentang Demorkasi), Ketua Bawaslu Republik Indonesia, Abhan mengutip yang dikatakan oleh Saptjipto Raharjo, bahwa mengonstasikan bahwa pemilu dan hukum di Indonesia, kondisinya ditentukan mulai dari persoalan objektif meliputi: 1. Reformasi dan krisis bangsa; 2. Pemilu: tradisi model baru, 3. Dimensi waktu dan soal teknis, 4. Kondisi geografis atau Negara Kepulauan, 5. Pemilu yang mahal, ${ }^{10}$ dari kutipan ini sudah digambarkan oleh Abhan bahwa permasalahan Pemilu dalam pengawasan salah satunya adalah daerah kepulauan, yang merupakan kendala tersendiri dalam pengawasan yang dilakukan oleh Bawaslu baik secara nasional sampai pada pengawas tempat pemungutan suara (Panwas TPS).

Ciri daerah kepulauan merupakan ciri dari bangsa ini dan tidak bisa dinafikan, namun harus dicari strategi penanggulangannya. Dengan daerah kepulauan jarak antara satu pulau dan pulau yang lain menimbulkan pengawasan yang mahal, dan aksebilitas pehubungan laut dan udara merupakan kendala tersendiri.

Dalam lampiran II Undang-undang Nomor 7 tahun 2017 tentang Pemilu mengatur bahwa Provinsi Maluku mempunyai Komisioner yang berjumlah 5 orang, sedangkan 11 Kabupaten/Kota di Maluku mempunyai 3 orang kominsioner. dengan jumlah kominisioner yang minim tentunya membuat para komisioner harus bekerja keras, karena tidak semua komisioner mempunyai pengalaman tentang penegakan hukum, untuk itulah ketika melakukan perekrutan Panwas dibawahnya harus mengutamakan orang yang mempunyai pegalaman di bidang penegakan hukum, karena sebagaimana termaktub dalam penjelasan Pasal 117 ayat (1) huruf e, menyebutkan yang dimaksud dengan "memiliki kemampuan dan keahlian yang berkaitan dengan Penyelenggaraan Pemilu dan pengawasan Pemilu, antara lain memiliki pengetahuan dan keahlian di bidang penegakan hukum. mempunyai anggota Bawaslu yang mempunyai kemampuan pengetahuan dan keahlihan di bidang penegakan hukum (law enforcement).

10 Teguh Prasetyo, (2017) Pemilu Bermartabat (Reorientasi Pemikiran Baru tentang Demorkasi), Jakarta : Rajawali Pers. Hal 145 
Putusan Mahkamah Konstitusi atas perkara nomor 31/PUU-XVI/2018, menurut penulis merupakan hal yang tepat, Pemilu 2019 kita akan mengahadapi Pemilihan Presiden/Wakil Presiden sekaligus dengan Pemilu legislatif, memberi beban berat pada penyelenggara di Kabupaten/Kota, karena harus melihat kondisi wilayah, ada wilayah di Maluku yang harus ditempuh dengan berjalan kaki menembus hutan dan sungai karena tidak ada akses jalan raya, ada wilayah di Maluku yang tidak bisa diakses karena kendala cuaca karena tidak dapat ditempuh dengan jalan darat. dengan menambah sumber daya manusia dari 3 menjadi 5 orang untuk KPU tentunya harus juga dilakukan hal yang sama dengan Bawaslu, karena dalam Pasal 1 ayat 7 Undang-undang Nomor 7 Tahun 2017 tentang Pemilu menyebutkan Bawaslu merupakan salah satu penyelenggara pemilu. Komisoner Kabupaten/Kota di Maluku yang hanya berjumlah 3 orang sangatlah sulit untuk menjalankan tugasnya, kecuali Kota Ambon yang sudah memiliki akses tranportasi yang baik. Fungsi Bawaslu Provinsi dan Kabupaten/Kota adalah

Bawaslu Provinsi melakukan pengawasan terhadap:

a) tahapan penyelenggaraan Pemilu di wilayah provinsi yang meliputi:

1. Pemutakhiran data pemilih berdasarkan data kependudukan dan penetapan daftar pemilih sementara dan daftar pemilih tetap;

2. Verifikasi partai politik calon Peserta Pemilu;

3. Pencalonan yang berkaitan dengan persyaratan dan tata cara pencalonananggota DPD, anggota DPRD Provinsi dan verifikasi pencalonan gubernur;

4. Proses penetapan calon anggota DPD, DPRD Provinsi, dan calon gubernur;

5. Pelaksanaan kampanye dan dana kampanye

6. Pengadaan logistik Pemilu dan pendistribusiannya;

7. Pelaksanaan pemungutan suara dan penghitungan suara hasil Pemilu;

8. Pelaksanaan seluruh proses penghitungan suara di wilayah kerjanya; 
9. Pergerakan surat suara dari tingkat TPS sampai ke PPK;

10. Proses rekapitulasi suara dari seluruh kabupaten/kota yang dilakukan oleh KPU Provinsi;

11. Pelaksanaan penghitungan dan pemungutan suara ulang, Pemilu lanjutan, dan Pemilu susulan; dan

12. Proses penetapan hasil Pemilu di wilayah provinsi.

b) menindaklanjuti Temuan dan Laporan Pelanggaran Pemilu;

c) pelaksanaan tindak lanjut rekomendasi Pengawas Pemilu; dan

d) pelaksanaan putusan/keputusan di wilayah provinsi, yang terdiri atas:

1. Putusan DKPP;

2. Putusan pengadilan mengenai pelanggaran dan sengketa Pemilu;

3. Putusan/keputusan Bawaslu, Bawaslu Provinsi, dan Bawaslu Kabupaten/ Kota;

4. Keputusan KPU, KPU Provinsi, dan KPU Kabupaten/Kota; dan

5. Keputusan pejabat yang berwenang atas pelanggaran netralitas aparatur sipil negara, netralitas anggota Tentara Nasional Indonesia, dan netralitas anggota Kepolisian Republik Indonesia.

Bawaslu Kabupaten/Kota melakukan pengawasan terhadap:

a) tahapan penyelenggaraan Pemilu di wilayah kabupaten/kota yang meliputi:

1. Pemutakhiran data pemilih berdasarkan data kependudukan dan penetapan daftar pemilih sementara dan daftar pemilih tetap;

2. Verifikasi partai politik calon Peserta Pemilu; 
3. Pencalonan yang berkaitan dengan persyaratan dan tata cara, calon anggota DPD, anggota DPRD Kabupaten/Kota dan verifikasi pencalonan bupati/wali kota;

4. Proses penetapan calon anggota DPRD Kabupaten/Kota dan calon bupati/wali kota;

5. Penetapan calon anggota DPRD Kabupaten/Kota dan calon bupati/wali kota;

6. Pelaksanaan kampanye di wilayah kabupaten/kota;

7. Pengadaan logistik Pemilu dan pendistribusiannya;

8. Pelaksanaan pemungutan suara dan penghitungan suara hasil Pemilu;

9. Pergerakan surat suara dari tingkat TPS sampai ke PPK;

10. Pergerakan surat suara dan/atau berita acara rekapitulasi hasil penghitungan perolehan suara di tingkat kecamatan;

11. Proses rekapitulasi suara yang dilakukan oleh KPU Kabupaten/Kota dari seluruh kecamatan;

12. Pelaksanaan pemungutan dan penghitungan suara ulang, Pemilu lanjutan, dan Pemilu susulan; dan

13. Proses penetapan hasil Pemilu anggota DPRD Kabupaten/Kota dan pemilihan bupati/wali kota.

b) menindaklanjuti Temuan dan Laporan Pelanggaran Pemilu;

c) pelaksanaan sosialisasi penyelenggaraan Pemilu;

d) pelaksanaan tindak lanjut rekomendasi Pengawas Pemilu; dan

e) pelaksanaan putusan/keputusan di wilayah kabupaten/kota, yang terdiri atas:

1. Putusan DKPP; 
2. Putusan pengadilan mengenai pelanggaran dan sengketa Pemilu;

3. Putusan/keputusan Bawaslu, Bawaslu Provinsi, dan Bawaslu Kabupaten/ Kota;

4. Keputusan KPU, KPU Provinsi, dan KPU Kabupaten/Kota; dan

5. Keputusan pejabat yang berwenang atas pelanggaran netralitas aparatur sipil negara, netralitas anggota Tentara Nasional Indonesia, dan netralitas anggota Kepolisian Republik Indonesia.

\section{Penegakan Hukum Pemilu di Maluku}

Kebijakan penegakan hukum harus dilakukan apabila tidak ada aturan yang mengatur soal suatu permasalahan hukum. ${ }^{11}$ Fungsi Penegakan Hukum, Bawaslu membuat menarik sistem penangganan perkara pemilu di Indonesia, karena Bawaslu bertindak sebagai penegak hukum yang diberikan kewenangan untuk melakukan penyidikan dan penyelidikan, serta mempunyai fungsi yudikatif dengan menyidangkan perkara administrasi, sebuah hal yang menarik di Maluku.

Tabel 1. Rekapitulasi Laporan dan Temuan Pelanggaran Pemilihan Bupati dan Wakil Bupati serta Pemilihan Walikota dan Wakil Walikota Provinsi maluku

Tahun 2017

\begin{tabular}{llc}
\hline No & Kabupaten/Kota & Jumlah Laporan/Temuan \\
\hline 1 & Kabupaten Buru & 37 \\
\hline 2 & Seram Bagian Barat & 15 \\
\hline 3 & Kota Ambon & 48 \\
\hline 4. & Kabupaten Maluku Tenggara Barat & 29 \\
\hline 5. & Kabupaten Maluku Tengah & 14 \\
\hline & Total & 143 \\
\hline
\end{tabular}

11 Lokollo, L., Salamor, Y. B., \& Ubwarin, E. (2020). Kebijakan Formulasi Undang-undang Narkotika Dalam Legalisasi Penggunaan Ganja Sebagai Bahan Pengobatan di Indonesia. Jurnal Belo , Volume 5 Nomor 2 Tahun 2020. Hal 3. 
Sumber : Bawaslu Provinsi Maluku

Ket : Perkara yang tidak ditindak dilanjuti karena, pelapor tidak datang dalam pembuktian, kurangnya bukti, bukan merupakan pelanggaran pemilu, adanya rekomendasi Sentral Gakumdu bahwa perbuatan tersebut bukan merupakan tindak pidana.

Pada dugaan tindak pidana pemilu, penyelidikan, penyidikan, penuntutan, dan pemeriksaan tindak pidana Pemilu dilakukan berdasarkan Undang-Undang Nomor 8 Tahun 1981 tentang Hukum Acara Pidana, kecuali ditentukan lain dalam Undangundang Nomor 7 tahun 2017 tentang Pemilu. Tahapan Penanggan dan Penyelesaian Tindak Pidana Pemilu.

a) Laporan/temuan, (1x24 harus diserahkan kepada pihak Kepolisian sejak ditetapkan sebuah perkara merupakan tindak pidana) Pengawas Pemilu (melakukan analisis, menentukan syarat formil dan syarat materil)

b) Polri (Penyidik) dalam Sentra Gakumdu melakukan pengkajian apakah perbuatan yang dilakukan termasuk dalam tindak pidana, jika ia maka penyidik akan melakukan penyidikan lanjutan, namun jika diangap cukup bukti yang dikumpulkan Bawaslu maka akan langsung dibuatkan Berita Acara Pemeriksaan (BAP), dan mengusulkan kepada Jaksa Penuntut Umum (Tahap I). (1x24 jam Penyelidik harus mengumpulkan bukti disertai BAP, dan 14 Hari Penyidik wajib menyerahkan BAP ke Jaksa Penuntut Umum)

Bagi penulis ini hal yang tidak mungkin, jika Penyelidik hanya diberikan waktu 1x24 untuk mencari bukti permulaan, hal ini yang sering membuat perkara pidana pemilu dianggap tidak memiliki bukti permulaan yang cukup sehingga dihentikan. Apalagi seperti Kabupaten Kepulauan Aru atau Kabupaten Maluku Barat Daya, waktu 1x24 Jam untuk seorang penyelidik menemukan bukti permulaan yang cukup. hal ini juga sama dengan Penyidik yang diberikan waktu oleh Undang-undang hanya 14 hari. 
c) Jaksa Penuntut Umum (JPU) melakukan pemeriksaan BAP barang bukti yang telah dikumpulkan dan menyatakan bahwa berkas telah lengkap maka akan dilakukan tahap II. Namun Jaksa mengembalikan kepada Penyidik BAP yang telah diterima 3 hari setelah diserahkan (Tahap I) dan penyidik wajib melengkapi paling BAP paling lama 3 hari,

d) JPU melanjutkan ke Pengadilan Negeri untuk segera ditentukan hari persidangannya. JPU mempunyai 5 Hari waktu melakukan pra-penuntutan, BAP tersebut harus dilimpahkan kepada Pengadilan Negeri

e) Pengadilan Negeri memeriksa, mengadili, dan memutus perkara tindak pidana Pemilu paling lama 7 hari setelah pelimpahan berkas perkara dan dapat dilakukan dengan tanpa kehadiran terdakwa.

f) Banding, permohonan banding diajukan paling lama 3 hari setelah putusan dibacakan.

g) Pengadilan Negeri melimpahkan berkas perkara permohonan banding kepada Pengadilan Tinggi paling lama 3 hari setelah permohonan banding diterima

h) Pengadilan Tinggi paling lama 7 hari harus sudah memutuskan perkara tersebut. dan putusan ini bersifat final, merupakan upaya hukum terakhir.

Sedangkan untuk dugaan pelanggaran administrasi Bawaslu mempunyai tahapan penanganan sebagai berikut :

a. Laporan/temuan, laporan dan temuan tersebut yang berikan harus memenuhi syarat materiil dan syarat formiel. (waktu Temuan tidak melebihi ketentuan batas waktu paling lama 7 (tujuh) hari sejak diketahui dan/atau ditemukan). Laporan Dugaan Pelanggaran Pemilihan disampaikan kepada Bawaslu, Bawaslu Provinsi, atau Panwas Kabupaten/Kota paling lama 7 (tujuh) hari sejak diketahuinya dan/atau ditemukannya Pelanggaran Pemilihan.

b. Bawaslu, Bawaslu Provinsi, atau Panwas Kabupaten/Kota dapat melimpahkan atau meneruskan Laporan Dugaan Pelanggaran Pemilihan sebagaimana dimaksud dalam Pasal 7 secara berjenjang kepada pengawas Pemilihan untuk ditindaklanjuti. 
c. Bawaslu mempunyai fungsi baru sebelum masuk pada tahap adjudkasi, Bawaslu dapat melakukan mediasi, kepada para pihak jika mediasi tidak berhasil maka akan lanjut dengan proses adjudikasi.

d. Dalam hal Laporan Dugaan Pelanggaran tidak memenuhi syarat formal tetapi memenuhi syarat materiil, menjadi informasi awal adanya dugaan pelanggaran yang ditindaklanjuti oleh pengawas Pemilihan dengan melakukan penelusuran untuk dapat dijadikan Temuan.

e. Dalam hal Laporan Dugaan Pelanggaran yang tidak memenuhi syarat materiil, Bawaslu atau pengawas Pemilihan melakukan kajian bahwa laporan tidak dapat diterima.

Penulis berpikir bahwa dengan wilayah Maluku bebentuk kepulauan, akan sulit untuk menjalankan sistem peradilan yang baik, baik untuk perkara administrasi, tindak pidana pemilu maupun sengketa pemilihan. Menurut penulis untuk itu perlu adanya Pembentukan peradilan "Zitting Plaast”. Zitting Plaats adalah tempat-tempat sidang di luar pengadilan yang berlokasi di dalam wilayah hukum pengadilan dan berfungsi sebagai tempat sidang tetap untuk penyelenggaraan persidangan semua jenis perkara yang diajukan para pencari keadilan. Dengan sistem ini maka Pengadilan dapat menjemput bola ke lapangan tanpa harus dibawah ke Pengadilan Negeri terdekat. Sedangkan untuk masalah jarak, transportasi, dan cuaca, biasanya mensiasati dengan menerima bukti laporan melalui telephon atau telephon satelit, short message service, Whatsapp atau media komunikasi lain dari pengawas dilapangan hal ini sesuai dengan Pasal 31 Perbawaslu Nomor 18 Tahun 2017 jo Perbawaslu Nomor 18 Tahun 2018 tentang Tata Cara Penyelesaian Sengketa Proses Pemilihan Umum. Frets Mouw salah satu komisioner di Bawaslu Kabupaten Maluku Tenggara dan Jefry Lamers Komisioner di Bawaslu Kabupaten Maluku Tenggara Barat, mengatakan yang pada intinya, bahwa di era revoluisi industri 4.0 ini sangat membantu karena pengawasan yang dilakukan terbantu oleh kemajuan teknologi dalam bidang komunikasi, trobosan ini dilakukan karena Bawaslu dikejar dengan waktu yang sangat singkat.

\section{Pengawasan Wilayah Kepulauan}

DOI: https://doi.org/10.30598/belovol6issue1page32-47 
Pegawasan adalah salah satu unsur penting dalam penegakan hukum dan mencegah terjadinya tindak pidana. ${ }^{12}$ Dengan rentan kendali yang luas, Bawaslu Provinsi Maluku dan Bawaslu Kabupaten/Kota di Maluku harus melakukan suatu trobosan dalam meningkatkan partisipasi pemilih dan pengawasan, Jumlah Bawaslu Provinsi dan Kabupaten/Kota tidak akan mampu secara baik mengawasi untuk itu perlu pelibatan partisipatif masyarakat dalam Pimilu tentu ditekankan kepada pemilih dan kelompok masyarakat yang lebih luas. Adapun prinsip pengawasan harus yang didorong oleh akurasi dan kecepatan informasi terkait pelanggaran. Artinya, keterbukaan informasi tentang pimilu harus dapat diakses oleh masyarakat pengawasan akurat. Misalnya, terkait penyertaan bukti dan saksi, agar masyarakat yang melaksanakan pengawasan merasa terlindungi atas informasi yang didapatkannya. ${ }^{13}$

Masyarakat adat adalah "Komunitas Adat, masyarakat dan bangsa adalah mereka yang, memiliki kesinambungan sejarah dengan pra-invasi dan pra-kolonial masyarakat yang dikembangkan di wilayah mereka, menganggap diri mereka berbeda dari sektor lain dari masyarakat sekarang berlaku di wilayah-wilayah, atau bagian dari mereka. Mereka membentuk saat ini sektor non-dominan masyarakat dan bertekad untuk melestarikan, mengembangkan dan mengirimkan ke generasi masa depan wilayah leluhur mereka, dan identitas etnik mereka, sebagai dasar kelangsungan mereka sebagai masyarakat, sesuai dengan pola budaya mereka sendiri, institusi sosial dan sistem hukum. Komunitas ini harusnya dimanfaatkan secara baik. Pelatihan dan sosialisasi penting kepada masyarakat adat untuk meningkatkan pengawasan, dengan pengawasan yang baik maka akan terlihat hasil pemilu yang baik pula.

\section{Kesimpulan}

Fungsi Bawaslu Provinsi, Kota Kabupaten/Kota diperluas dengan UndangUndang, Bawaslu dapat melaksanakan Mediasi, dan Proses Adjudikasi, namun dibatasi

${ }^{12}$ Latukau, F. (2020). Pengadopsian UNCAC Mengenai Pengembalian Aset Hasil Korupsi Yang Dibawa Atau Disimpan Ke Luar Negeri Dalam Penegakan Hukum Indonesia. JURNAL BELO, Volume 5 Nomor 1. Hal 10.

${ }^{13}$ Adela, F.P.\&Truna, D.S Vol. 3 No. 1 2017, , Partisipasi Rakyat Dalam Pengawasan Pilkada, Antisipasi Tingginya Angka Golput Di Pilkada Sumut. Hal 107-118

DOI: https://doi.org/10.30598/belovol6issue1page32-47 
dengan waktu yang sangat singkat, sementara rentan kendali yang luas, dengan 92 (Sembilan puluh dua) \% wilayah laut dan 8 (delapan) \% wilayah darat. Hasil penelitian menunjukan bahwa dengan rentan waktu yang cepat namun wilayah yang luas maka di era revolusi 4.0, penegakan hukum dengan memakai basis teknologi informasi dan komunikasi, serta memakai peradilan dengan metode zitting plaast, dengan dua sistem ini maka tidak akan terkendala waktu dan rentan wilayah. kesimpulannya dengan memakai sistem berbasis teknologi, dan Pembentukan peradilan Zitting Plaast baik maka laporan dan temuan yang diproses oleh Bawaslu Provinsi, dan Bawaslu Kota/Kabupaten tidak akan mengalami kendala.

\section{Daftar Pustaka}

\section{Jurnal}

[1] Katja, G. (2013 ). Adat and Indigeneity in Indonesia: Culture and Etitlements between Heteronomy and Self-Ascription. Indigenous Peoples in International Law dalam Göttingen Studies in Cultural Property , 7 (1) 18-30.

[2] Latukau, F. (2020). Pengadopsian UNCAC Mengenai Pengembalian Aset Hasil Korupsi Yang Dibawa Atau Disimpan Ke Luar Negeri Dalam Penegakan Hukum Indonesia. Jurnal Belo , 5 (1). 10. DOI : https://doi.org/10.30598/belovol5issue1page10-31

[3] Lokollo, L., Salamor, Y. B., \& Ubwarin, E. (2020). Kebijakan Formulasi Undang-undang Narkotika Dalam Legalisasi Penggunaan Ganja Sebagai Bahan Pengobatan di Indonesia. Jurnal Belo , 5 (2) 3. DOI : https://doi.org/10.30598/belovol5issue2page1-20

[4] Mawati, E., Takariawan, A., \& Sulistiani, L. (2020). Kebijakan Hukum Pidana Mengenai Rehabilitasi Psikososial Korban Tindak Pidana Terorisme Dalam Sistem Peradilan Pidana. Jurnal Belo, Volume 5, Nomor 2, 34-56. DOI : https://doi.org/10.30598/belovol5issue2page34-56

[5] Patty, J. (2020). jmp Pelarangan Mantan Terpidana Korupsi Menjadi Calon Kepala Daerah Agar Menimbulkan Efek Jera. Jurnal Belo, 5 (1), 1-9. DOI : https://doi.org/10.30598/belovol5issue1page1-9

[6] Rahmatunnisa, M. (2017). MENGAPA INTEGRITAS PEMILU PENTING?, Jurnal Bawaslu, 3 (1), 1-11. DOI : https://doi.org/10.14203/jpp.v16i1.782 
[7] Zuhro, R. S. (2019). DEMOKRASI DAN PEMILU PRESIDEN 2019. Jurnal Penelitian Politik LIPI , 16 (1) 69-81

\section{Buku.}

[8] Amirudin, e. (2016). Pengantar Metode Penelitian Hukum. Jakarta: RajaGrafindo Prasada.

[9] David, H. (2017). Globalization/Anti-Globalization : Beyond the Great Divide Polity. Cambridgeshire: Cambridge.

[10] Manan, B. (2010). Teori dan Politik Konstitusi. Jakarta: Direktorat Jenderal Pendidikan Tinggi, Departemen Pendidikan Nasional.

[11] Muchsan. (2017). Sistem Pengawasan Terhadap Perbuatan Aparat Pemerintah Dan Peradilan Tata Usaha Negara Di Indonesia,. Yogyakarta: Liberty.Schumpeter, J. (2016). Capitalism, Socialism \& Democracy . London: Routledge.

[12] Soekanto, S. (2015). Pengantar Penelitian Hukum. Jakarta: UI Press. 